\title{
Novel Zinc Finger Transcription Factor ZFP580 Facilitates All-Trans Retinoic Acid -Induced Vascular Smooth Muscle Cells Differentiation by Raro-Mediated PI3K/Akt and ERK Signaling
}

\author{
Shuping Weia,b Jingjing Zhang ${ }^{c}$ Biao Han ${ }^{a}$ Jianxun Liuc Xiaohui Xiang ${ }^{\mathrm{d}}$ \\ Mei Zhang ${ }^{c}$ Shihai Xiad ${ }^{d}$ Wencheng Zhang $^{d}$ Xizheng Zhang ${ }^{a}$ \\ aInstitute of Medical Service and Technology, Academy of Military Science, Tianjin, ${ }^{b}$ Department of \\ Human Morphology, Logistics University of Chinese People's Armed Police Force, Tianjin, 'Department \\ of Cardiology, Logistics University of Chinese People's Armed Police Force, Tianjin, ${ }^{\mathrm{d} D e p a r t m e n t}$ of \\ Hepatopancreatobiliary and Splenic Medicine, Logistics University of Chinese People's Armed Police \\ Force, Tianjin, China
}

\section{Key Words}

Zfp580 • Vascular smooth muscle cells • Differentiation • All-trans retinoic acid

\begin{abstract}
Background/Aims: Phenotypic switching of vascular smooth muscle cells (VSMC) plays a vital role in the development of vascular diseases. All-trans retinoic acid (ATRA) is known to regulate VSMC phenotypes. However, the underlying mechanisms remain completely unknown. Here, we have investigated the probable roles and underlying mechanisms of the novel $\mathrm{C} 2 \mathrm{H} 2$ zinc finger transcription factor ZFP580 on ATRA-induced VSMC differentiation. Methods: VSMCs were isolated, cultured, and identified. VSMCs were infected with an adenovirus encoding ZFP580 or Ad-siRNA to silence ZFP580. The expression levels of ZFP580, SM $\alpha$-actin, SM22 $\alpha$, SMemb, RAR $\alpha, R A R \beta$, and RAR $y$ were assayed by Q-PCR and western blot. A rat carotid artery injury model and morphometric analysis of intimal thickening were also used in this study. Results: ATRA caused a significant reduction of VSMC proliferation and migration in a doseand time-dependent manner. Moreover, it promoted VSMC differentiation by enhancing expression of differentiation markers and reducing expression of dedifferentiation markers. This ATRA activity was accompanied by up-regulation of ZFP580, with concomitant increases in RAR $\alpha$ expression. In contrast, silencing of the RAR $\alpha$ gene or inhibiting RAR $\alpha$ with its antagonist Ro41-5253 abrogated the ATRA-induced ZFP580 expression. Furthermore, ATRA binding to RAR $\alpha$ induced ZFP580 expression via the PI3K/Akt and ERK pathways. Adenovirusmediated overexpression of ZFP580 promoted VSMC differentiation by enhancing expression S. Wei, J. Zhang and B. Han contributed equally to this work.


Wei et al.: ZFP580 Facilitates ATRA-Induced VSMC Differentiation by Rara-Mediated

PI3K/Akt and ERK Signaling

of SM22 $\alpha$ and SM $\alpha$-actin and reducing expression of SMemb. In contrast, silencing ZFP580 dramatically reduced the expression of differentiation markers and increased expression of dedifferentiation markers. The classic rat carotid artery balloon injury model demonstrated that ZFP580 inhibited proliferation and intimal hyperplasia in vivo. Conclusion: The novel zinc finger transcription factor ZFP580 facilitates ATRA-induced VSMC differentiation by the RAR $\alpha$ mediated PI3K/Akt and ERK signaling pathways. This might represent a novel mechanism of regulation of ZFP580 by ATRA and RAR $\alpha$, which is critical for understanding the biological functions of retinoids during VSMC phenotypic modulation.

\section{Introduction}

Vascular proliferative diseases, including atherosclerosis and restenosis after percutaneous coronary interventions, are caused by the combined effects of multiple cell types such as vascular smooth muscle cells (VSMCs), macrophages, and endothelial cells [1]. Inflammation, phenotypic switching, and proliferation of VSMCs are involved in the development of these diseases [2]. Vascular injury, which includes non-denuding endothelial functional injury or denuding endothelial and intimal injury with or without medial damage, represents a critical initiating event in the pathogenesis of various vascular proliferative diseases including restenosis [3]. In response to vascular injury, VSMCs exhibit phenotypic change characterized by a loss of contractility and abnormal proliferation, migration, and matrix synthesis [4]. VSMCs, as the major effector cells in this process, coordinate and synchronize immensely complex inflammatory, proliferative, and differentiation programs [5]. Despite the importance of VSMC phenotypic switching in the development of vascular diseases, the exact mechanisms controlling VSMC phenotypes are not completely understood. Therefore, understanding the molecular mechanisms regulating VSMC phenotypes is helpful for the prevention and treatment of vascular proliferative diseases.

Vasoactive substances and their receptors, cytokines, growth factors, and cellular signaling molecules have been reported to be involved in the regulation of VSMC differentiation, migration, and proliferation [6-8]. Retinoids are derivatives of vitamin A and are involved in a number of biological processes, including vision, embryogenesis, and differentiation of blood, skin, and tumor cells [9]. Therefore, retinoids are clinically used in oncological treatments, principally against acute promyelocytic leukemia and hyperproliferative skin diseases [10]. Moreover, it was found that retinoids could inhibit inflammation, thrombosis, platelet adhesion and aggregation, and stimulate fibrinolysis [11]. Predominantly, all-trans retinoic acid (ATRA) and its stereoisomer 9-cis retinoic acid (9cRA) were found to be very potent metabolites of retinol, exerting pleiotropic effects on many different biological processes [12]. These effects are mediated by binding to retinoic acid receptors (RARs) and retinoid X receptors (RXRs), which are ligand-dependent transcription factors that belong to the nuclear receptor superfamily [13]. Previous in vitro studies have shown that ATRA inhibits platelet-derived growth factor-BB and serum-induced SMC growth [14]. These effects were most probably mediated by five of six retinoid receptors that were expressed in these vascular SMCs. In addition, the first in vivo study in rat carotid arteries demonstrated that ATRA reduces neointimal thickening and promotes remodeling after endothelial denudation [15]. There is considerable evidence supporting an important role for ATRA in the maintenance and possible establishment of a SMC-differentiated phenotype. However, the molecular mechanism by which ATRA influences VSMC differentiation remains to be elucidated.

Recent data have indicated that numerous transcription regulators mediate responses to inflammation, proliferation, and differentiation in vascular tissues [16-18]. Of these transcriptional regulators, the mammalian Krüppel-like factor (KLF) family of zinc finger transcription factors has recently received increasing attention. KLF plays important roles in vasculature and both developmental and pathological vascular processes [19-21]. The novel zinc finger transcription factor ZNF580, whose protein structure is similar to that of 


\section{Cellular Physiology Cell Physiol Biochem 2018;50:2390-2405

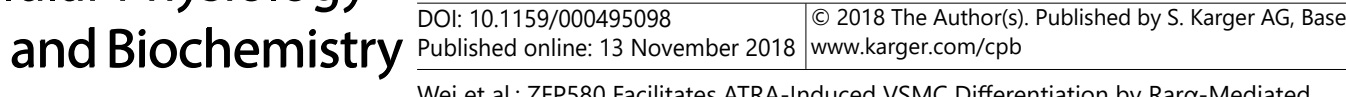 \\ PI3K/Akt and ERK Signaling}

KLF, was initially cloned by our group [22]. The murine homolog of ZNF580, namely, ZFP580, was subsequently cloned in our laboratory and investigated in rats [23]. Bioinformatic analyses revealed that ZFP580 is also a C2H2 (Cys2-His2) zinc-finger protein that contains 172 amino acids, and $97 \%$ of the amino acid sequence is consistent with ZNF580. Our previous study has shown that ZFP580 had an anti-apoptotic effect on myocardial ischemia reperfusion injury [24]. The expression of ZFP580 significantly changed in VSMCs with intimal neovascularization. In addition, ZFP580 plays an important regulatory role in EPC-EC differentiation via the eNOS/NO pathway $[25,26]$. Therefore, we hypothesized that ZFP580 might play an important role in the process of VSMC phenotypic switching and could be used as a new molecular target for treating such diseases.

Our preliminary experimental results showed that ATRA significantly induces ZFP580 expression and promotes the differentiation process in VSMCs. This study was designed to investigate the probable roles of ZFP580 and underlying mechanisms by which ZFP580 influences ATRA-induced VSMCs differentiation. Our results indicate that the transcription factor ZFP580 plays a vital role in inducing differentiation of VSMCs and thereby provide new insights into the biological functions of retinoids during VSMC phenotypic modulation.

\section{Materials and Methods}

\section{Reagents}

All-trans retinoic acid (ATRA) was purchased from Sigma-Aldrich (St. Louis, MO, USA). Fetal bovine serum (FBS; origin, USA) was purchased from Capricorn Scientific GmbH (Ebsdorfergrund, Germany). Alexa Fluor 488 phalloidin was purchased from Abcam (Cambridge, UK). Lipofectamine ${ }^{\mathrm{TM}} 2000$ Reagent was purchased from Invitrogen (Carlsbad, CA, USA). Antibodies against RAR $\alpha$, RAR $\beta$, RAR $\gamma$, and SMemb were from Santa Cruz Biotechnology (Santa Cruz, CA, USA). Anti-ZFP580, anti-SM22 $\alpha$, anti-SM $\alpha$-actin, antiERK1+ERK2, anti-pERK, anti-p38, anti-p-p38, anti-Akt1/2/3, anti-pAkt1/2/3, anti-proliferating cell nuclear antigen (PCNA), and anti- $\beta$-actin were from Abcam. Secondary antibodies were anti-IgG+IgM from mouse and rabbit conjugated with peroxidase (Pierce, Rockford, IL, USA). All sterile cell culture materials were obtained from Greiner (Frickenhausen, Germany), unless stated otherwise.

\section{Cell culture and treatment}

VSMCs from the thoracic aorta of Sprague Dawley (SD) rats (5-6 weeks old) were isolated using a standard enzymatic digestion technique [27]. Rats were sacrificed with an overdose of pentobarbital sodium $(100 \mathrm{mg} / \mathrm{kg})$ by intraperitoneal injection before the aorta was excised. Cells were cultured and passaged in Dulbecco's modified Eagle medium (DMEM) supplemented with $10 \% \mathrm{FBS}, 100 \mu \mathrm{g} / \mathrm{mL}$ penicillin, and 100 $\mu \mathrm{g} / \mathrm{mL}$ streptomycin at $37^{\circ} \mathrm{C}$ in a humidified atmosphere with $5 \% \mathrm{CO}_{2}$. A total of 3-8 cell passages were used for all experiments. The growth of VSMC cultures were arrested by incubation in serum-free DMEM for $12 \mathrm{~h}$ and then treated with different concentrations of ATRA $(0,5,10,20 \mu \mathrm{mol} / \mathrm{L})$ for $24 \mathrm{~h}$ or with ATRA $(20 \mu \mathrm{mol} / \mathrm{L})$ for different time intervals $(0,24,48,72 \mathrm{~h})$. For the inhibition studies, cells were pretreated with $20 \mu \mathrm{mol} / \mathrm{L}$ PD98059 (Abcam ab146592), $20 \mu \mathrm{mol} / \mathrm{L} \mathrm{LY294002} \mathrm{(Abcam} \mathrm{ab146589),} \mathrm{and} 20 \mu \mathrm{mol} / \mathrm{L}$ SB203580 (Abcam ab146593) in DMSO for $2 \mathrm{~h}$, and with $20 \mu \mathrm{mol} / \mathrm{L}$ Ro41-5253 in DMSO for $1 \mathrm{~h}$ before ATRA application.

siRNA-mediated gene silencing

Small-interfering RNA (siRNA) duplexes were designed and synthesized by Sangon Biotech (Shanghai, China) for use in silencing RAR $\alpha$. The siRNA sequences against RAR $\alpha$ (si-RAR $\alpha$ ) were $5^{\prime}$-GCAAGUACACUACGAACAATT- $3^{\prime}$ and $5^{\prime}$-UUGUUCGUAGUGUACUUGCTT- ${ }^{\prime}$. The nonspecific siRNA sequences (si-NS) were 5'-UUCUCCGAACGUGUCACGUTT-3' and 5'-ACGUGACACGUUCGGAGAATT- $3^{\prime}$. Cells were transfected with siRNAs using Lipofectamine ${ }^{\mathrm{TM}} 2000$ Reagent (Thermo Fisher Scientific, Waltham, MA, USA) as recommended by the manufacturer and used for experiments $48 \mathrm{~h}$ later.

Adenovirus infection of VSMCs

Ad-ZFP580, a recombinant adenovirus encoding ZFP580, was generated by subcloning cDNA encoding the total length of ZFP580 into an adenoviral vector, and the parental adenoviral vector was 


\section{Cellular Physiology Cell Physiol Biochem 2018;50:2390-2405 \\ \begin{tabular}{ll|l} 
and Biochemistry & $\begin{array}{l}\text { DOI: 10.1159/000495098 } \\
\text { Published onlIne: 13 November } 2018\end{array}$ & $\begin{array}{l}\text { (c) The Author(s). Published by S. Karger AG, Basel } \\
\text { www.karger.com/cpb }\end{array}$ \\
\hline
\end{tabular} \\ Wei et al.: ZFP580 Facilitates ATRA-Induced VSMC Differentiation by Rara-Mediated \\ PI3K/Akt and ERK Signaling}

used as an infection negative control (Ad-NC). In addition, an adenovirus encoding Ad-siZFP580 was used to suppress the expression of ZFP580. The forward and reverse primer sequences were ZFP580 siRNA (5'-ACTCGGACCTCAAGCCCTTTA-3' and 5'-TAAAGGGCTTGAGGTCCGAGT-3'), and a recombinant adenovirus expressing a scrambled siRNA-ZFP580 (Ad-si-scrambled) was used as a control; each of these constructs were synthesized by GenePharma (Shanghai GenePharma Co., China). Cells cultured at 70-80\% confluence were infected with Ad-ZFP580 or Ad-siZFP580 at different multiplicities of infection (150 and 200) for 48 $\mathrm{h}$ before further treatment.

Quantitative real-time polymerase chain reaction

Total RNA was extracted from VSMCs using TRIzol reagent (Sigma-Aldrich), followed by cDNA synthesis using oligo (dT) and MMLV reverse transcriptase (Takara, Tokyo, Japan). The resulting cDNAs were used as templates for quantitative real-time polymerase chain reaction (Q-PCR) conducted with SYBR Green on an ABI Prism 7900 sequence detection PCR system (Applied Biosystems, Foster City, CA, USA) according to the manufacturer's protocol. The sequences of these primers are listed in the table 1.

\section{Western blot}

Cells samples were homogenized in a radioimmunoprecipitation assay (RIPA) lysis PAGE sample loading buffer (containing 5\% 2-mercaptoethanol) and boiled for $10 \mathrm{~min}$. Equal amounts of proteins were loaded in each lane, separated by 6-15\% SDS-PAGE, and transferred to polyvinylidene difluoride membranes (0.22 $\mu \mathrm{m}$; Millipore, Billerica, MA, USA). The membranes were blocked with 5\% nonfat milk in Tris-buffered saline containing Tween 20 for $1 \mathrm{~h}$ at room temperature and then incubated overnight with anti-ZFP580 antibody (1:1000, Abcam, ab59015), anti-SM $\alpha$-actin antibody (1:200, Abcam, ab5694), antiSM22 $\alpha$ (1:1000, Abcam, ab14106), anti-SMemb (1:2000, Santa Cruz, sc-33729), anti-RAR $\alpha$ (1:1000, Santa Cruz, sc-551), RAR $\beta$ (1:1000, Santa Cruz, sc-552), RAR $\gamma$ (1:2000, Santa Cruz, sc-550), anti-ERK1/2 antibody (1:2000, Abcam, ab36991), anti-pERK antibody (1:10000, Abcam, ab50011), anti-p38 antibody (1:1000, Abcam, ab31828), anti-p-p38 antibody (1:1000, Abcam, ab45381), anti-Akt1/2/3 antibody (1:100000, Abcam, ab179463), anti-pAkt antibody (1:1000, Abcam, ab131443), anti-PCNA antibody (1:1000, Abcam, ab18197), and anti- $\beta$-actin (1:1000, Abcam, ab8224) at $4^{\circ} \mathrm{C}$. The membranes were washed extensively in Tris-buffered saline containing $0.1 \%(v / v)$ Tween 20 before incubation for $1 \mathrm{~h}$ with a secondary anti-rabbit or anti-mouse IgG (1:5000) conjugated to horseradish peroxidase (HRP). Protein bands were detected by the standard enhanced chemiluminescence (ECL; Amersham Biosciences, Little Chalfont, UK) method and quantified using a gel image analysis system.

\section{MTT colorimetric assay}

Mitogenic quiescence was induced in VSMCs $\left(1 \times 10^{4}\right.$ cells/well) seeded in 96-well plates by serum starvation for 12 hours. The cells were then treated with different concentrations of ATRA $(0,5,10,20$ $\mu \mathrm{mol} / \mathrm{L})$ for $24 \mathrm{~h}$ or with ATRA $(20 \mu \mathrm{mol} / \mathrm{L})$ for different time intervals $(0,24,48,72 \mathrm{~h})$. Cell proliferation was assayed by cleavage of the tetrazolium salt 3-(4, 5-dimethyl-2-thiazolyl)-2, 5-diphenyl-2-H-tetrazolium bromide (MTT). After cells were incubated with MTT for 4 hours at $37^{\circ} \mathrm{C}$, the culture medium was removed by inverting and tapping the plates, and $150 \mu \mathrm{L}$ of DMSO was added to each well. The spectrophotometric absorbance at $490 \mathrm{~nm}$ was then measured by an enzyme-linked immunosorbent assay (ELISA) reader (Titertek Multiscan MC, TitertekBerthold, Pforzheim, Germany).

Wound-healing assay

VSMCs were seeded into a six-well plate at a density of $2 \times 10^{5}$ cells/well, grown to confluence, and starved for $12 \mathrm{~h}$. The cell monolayer was scratched using a sterile $1000 \mathrm{~mL}$
Table 1. Primer sequences for Q-PCR

\begin{tabular}{lrc}
\hline Gene & Forward primer & Reverse primer \\
\hline SM $\alpha$-actin & ACTCTGGAGATGGCGTGACTC & GCGTTCATTCCCGATGGT \\
SM22 $\alpha$ & GCCGTGACCAAGAACGAT & CTCTGTTGCTGCCCATTTG \\
SMemb & ACCGAGAAGATCAATCCATC & AGATACTGGATGACCTTCTTG \\
RAR $\alpha$ & CACCTGAGCAAGACACAATGA & GCGAAGGCAAAGACCAAGT \\
RAR $\beta$ & ATGGCAGAGACCCAGTTGAG & GCAAGACAAAAGAAAGCACCA \\
RAR $\gamma$ & CACACCAGAAGAAGGCATCA & GGCAGATCGTCAGTCAGTCA \\
ZFP580 & TCAAGCCCTTTACTTGTGGTG & ACAGAGTGGGCAGGTGTGA \\
$\beta$-actin & TCCTCCTGAGCGCAAGTACTCT GCTCAGTAACAGTCCGCCTAGAA
\end{tabular}




\section{Cellular Physiology Cell Physiol Biochem 2018;50:2390-2405 \begin{tabular}{l|l|l} 
and Biochemistry Published onlıne: 13 November 2018 & $\begin{array}{l}\text { (c) } 2018 \text { The Author(s). Published by S. Karger AG, Basel } \\
\text { www.karger.com/cpb }\end{array}$ \\
\hline
\end{tabular} \\ Wei et al.: ZFP580 Facilitates ATRA-Induced VSMC Differentiation by Rar $\alpha$-Mediated \\ PI3K/Akt and ERK Signaling}

pipette tip (width of the scratch, $1 \mathrm{~mm}$ ) and left to recover for the next $24 \mathrm{~h}$ in freshly exchanged starvation medium (0.1\% serum-supplemented DMEM). VSMCs were then treated with different concentrations of ATRA $(0,5,10,20 \mu \mathrm{mol} / \mathrm{L})$ for $24 \mathrm{~h}$ or with ATRA (20 $\mu \mathrm{mol} / \mathrm{L})$ for different time intervals $(0,24,48,72 \mathrm{~h})$ and the influence on migration was monitored. Images of the scratch under light microscopy were taken after treatment; four different sites per scratch were monitored and evaluated to give an average value for each experimental condition. To ensure the very same area of each scratch was captured, perpendicular lines were drawn at the bottom side of the plates before cell seeding. The cell re-colonization rate was recorded by measuring the cell-free area of each scratch, using Cell Profiler software (www.cellprofiler.org, Broad Institute, Cambridge, MA, USA).

\section{Phalloidin staining and confocal laser scanning microscopy}

In triplicated independent experiments, VSMCs stimulated with ATRA ( $20 \mu \mathrm{mol} / \mathrm{L})$ or transfected with adenovirus were incubated in 4 -well chamber slides for $24 \mathrm{~h}$ at $37^{\circ} \mathrm{C}$ with $5 \% \mathrm{CO}_{2}$. The cells were fixed with $4 \%$ paraformaldehyde for $30 \mathrm{~min}$ at room temperature (RT), permeabilized for 30 min with PBS plus 0.01\% Triton X-100 for 30 min, and stained with Phalloidin (Abcam) for $1 \mathrm{~h}$ at RT followed by three washing steps for $10 \mathrm{~min}$. Confocal microscopy was performed with a Confocal Laser Scanning Microscopy System (Leica, Wetzlar, Germany). Pictures were taken from five optical fields $(\times 20)$ for each well, and cell shape was analyzed.

\section{Rat carotid artery injury model and morphometric analysis of intimal thickening}

Male Sprague Dawley rats (1-2 month-old) provided by the Animal Center of the Academy of Military Medical Sciences (Beijing, China) were used to perform this study. The investigation conforms to the Guide for the Care and Use of Laboratory Animals published by the US National Institutes of Health (NIH Publication 8th Edition, 2011). The animal experimental protocol was approved by the Animal Care and Use Ethics Committee of the Logistics University of the Chinese People's Armed Police Force. Balloon dilation of the left common carotid artery of male SD rats (250-300 g) was performed as previously described [28]. Briefly, rats were anesthetized by intra-peritoneal injection of pentobarbital sodium ( $30 \mathrm{mg} / \mathrm{kg}$ of bodyweight). A size $2 \mathrm{~F}$ embolectomy balloon catheter was inserted into the left common carotid via the external carotid artery. Then the inflated balloon was drawn gently toward the external carotid artery. After repeating this procedure three times, the catheter was removed. The injured artery was washed with phosphate-buffered saline and incubated for $20 \mathrm{~min}$ with $50 \mu \mathrm{L}$ of adenoviral vector $\left(1 \times 10^{9} \mathrm{TU} / \mathrm{ml}\right)$ expressing GFP or ZFP580. $\mathrm{SD}$ rats were sacrificed by intraperitoneal injection of ketamine $(1 \mathrm{~g} / \mathrm{kg}$ body weight $)$ and xylazine $(100 \mathrm{mg} /$ $\mathrm{kg}$ ) at the designated time and arteries were collected for real-time PCR and western blot assays or embedded in paraffin or OCT to be prepared into cross-sections. Vessel sections were analyzed by hematoxylin/eosin staining with a computer-based Image-Pro Morphometric System in a double-blind manner. The area of the residual lumen, the area circumscribed by the internal elastic lamina, and the area bounded by the external elastic lamina were measured directly. The degree of neointimal thickening was assessed using the intimato-media area ratio (I/M) and neointimal area. To detect the vascular cell replication rate in vivo, rats were intraperitoneally injected with bromodeoxyuridine (BrdU; $25 \mathrm{mg} / \mathrm{kg}$ ) at $18 \mathrm{~h}$ and $2 \mathrm{~h}$ before being sacrificed. The arteries were perfusion-fixed with 4\% paraformaldehyde in PBS under a pressure of $100 \mathrm{mmHg}$, and the segments were snap-frozen in OCT embedding compound. The cryosections of arterial segments were denatured with $1.5 \mathrm{~N} \mathrm{HCl}$ and subjected to immunofluorescent staining. For antigen retrieval, deparaffinized formalin-fixed sections were boiled for $10 \mathrm{~min}$ in $10 \mathrm{mM}$ sodium citrate (pH 6). Primary antibody (PCNA at 1:100 dilution) was incubated overnight at $4^{\circ} \mathrm{C}$ in $1 \%$ normal goat serum in phosphate buffered saline. Contralateral carotid arteries underwent the entire procedure apart from injury and served as the sham group. Rats in the control group were not subjected to any operation.

\section{Statistical analysis}

All data are presented as means \pm SEM (standard error of the mean) of at least three independent experiments. Comparisons between groups were analyzed by two-tailed Student's $t$-test or ANOVA procedures. Differences were considered statistically significant at a threshold of $P<0.05$ or $P<0.01$. 


\section{Cellular Physiology Cell Physiol Biochem 2018;50:2390-2405 \\ \begin{tabular}{ll|l} 
and Biochemistry & $\begin{array}{l}\text { DOI: 10.1159/000495098 } \\
\text { Published onlIne: 13 November } 2018\end{array}$ & $\begin{array}{l}\text { C) } 2018 \text { The Author(s). Published by S. Karger AG, Base } \\
\text { www.karger.com/cpb }\end{array}$ \\
\cline { 2 - 3 }
\end{tabular} \\ PI3K/Akt and ERK Signaling}

\section{Results}

ATRA inhibits cell proliferation and migration while promoting differentiation of VSMCs

To profile the effects of ATRA on VSMC phenotype modulation and biological behaviors, cells were incubated with different concentrations of ATRA $(0,5,10,20 \mu \mathrm{mol} / \mathrm{L})$ for $24 \mathrm{~h}$ or with ATRA $(20 \mu \mathrm{mol} / \mathrm{L})$ for different time intervals $(0,24,48,72 \mathrm{~h})$. Then changes in proliferation, migration, and the expression of marker genes were detected. MTT colorimetric assays (Fig. $1 \mathrm{~A}$ and B) and cell migration assays (Fig. 1C and D) showed that incubation with ATRA caused a dose-dependent and time-dependent inhibition of VSMC growth and motility. A significant inhibiting effect was observed by treatment with $20 \mu \mathrm{mol} / \mathrm{L}$ of ATRA for $24 \mathrm{~h}$.

We then examined the effect of ATRA on the expression of two VSMC differentiation markers, SM22 $\alpha$ and SM $\alpha$-actin, and the dedifferentiation marker embryonic vascular smooth muscle myosin heavy chain-B (SMemb) by Q-PCR and western blot. Treatment with ATRA increased expression of SM22 $\alpha$ and SM $\alpha$-actin, while decreasing SMemb levels in a dose-dependent (Fig. 1E and F) and time-dependent (Fig. 1G and H) manner. These findings suggest that ATRA inhibits cell proliferation and migration while promoting differentiation of VSMCs.

\section{ATRA-induced ZFP580 expression is RAR $\alpha$ dependent}

ATRA functions by binding to RARs and RXRs, which act as transcription factors when a ligand is bound. There are three types of RARs, namely RAR $\alpha, \operatorname{RAR} \beta$, and RAR $\gamma$, each of which is encoded by their respective genes. To explore the actual relationship between ZFP580 and RARs in ATRA-stimulated VSMCs, we first examined the expression of ZFP580 and RARs in response to ATRA signaling. ATRA increased the expression of ZFP580 and RAR $\alpha$ in a concentration- (Fig. 2A and B) and time-dependent (Fig. 2C and D) manner. As shown in Fig. $2 A-D, 24 \mathrm{~h}$ after $20-\mu \mathrm{mol} / \mathrm{L}$ ATRA treatment, ZFP580 and RAR $\alpha$ levels were elevated, and this increase was maintained until $72 \mathrm{~h}$ after treatment. However, unlike RAR $\alpha$, the expression levels of RAR $\beta$ and RAR $\gamma$ were little changed by ATRA treatment.

To further define whether RAR $\alpha$ mediated the induction of ZFP580 by ATRA or not, we knocked down endogenous RAR $\alpha$ by transfecting VSMCs with siRNAs against RAR $\alpha$ (si-RAR $\alpha$ ) or a control (si-NS). Transfection of si-RAR $\alpha$ downregulated endogenous RAR $\alpha$ expression. Moreover, the induction of ZFP580 by ATRA was significantly reduced in both mRNA and protein levels in the cells with RAR $\alpha$ knockdown (Fig. 2E and F). Furthermore, when VSMCs were treated with a RAR $\alpha$ antagonist (Ro41-5253) prior to the addition of ATRA, the blockade of RAR $\alpha$ signaling partially reduced the response of RAR $\alpha$ to ATRA (Fig. $2 \mathrm{G}$ and $\mathrm{H}$ ).

\section{ATRA induces ZFP580 expression via Akt and ERK pathways}

To test which signal pathways mediate ZFP580 expression in response to ATRA, we observed the effect of ATRA on the phosphorylation of p38, Akt, and ERK by western blot. As shown in Fig. 3A, the levels of phospho-Akt and phospho-ERK were increased within $15 \mathrm{~min}$ and persisted to $1 \mathrm{~h}$ after ATRA treatment, whereas p38 phosphorylation was not affected by ATRA under the same experimental conditions. The level of expression of the molecule did not change during this time course. To assess the importance of Akt and ERK signaling in ZFP580 expression, VSMCs were pretreated either with the Akt inhibitor LY294002, the ERK inhibitor PD98059, or the p38 inhibitor SB203580 for $2 \mathrm{~h}$ before exposure to ATRA. Pharmacological inhibition of Akt and ERK blocked ATRA-induced increases in ZFP580 levels, whereas inhibition of p38 did not affect the ZFP580 increase induced by ATRA (Fig. 3B). These results suggest that the Akt and ERK signaling pathways mediate the observed ATRA-induced ZFP580 protein stability in VSMCs. 


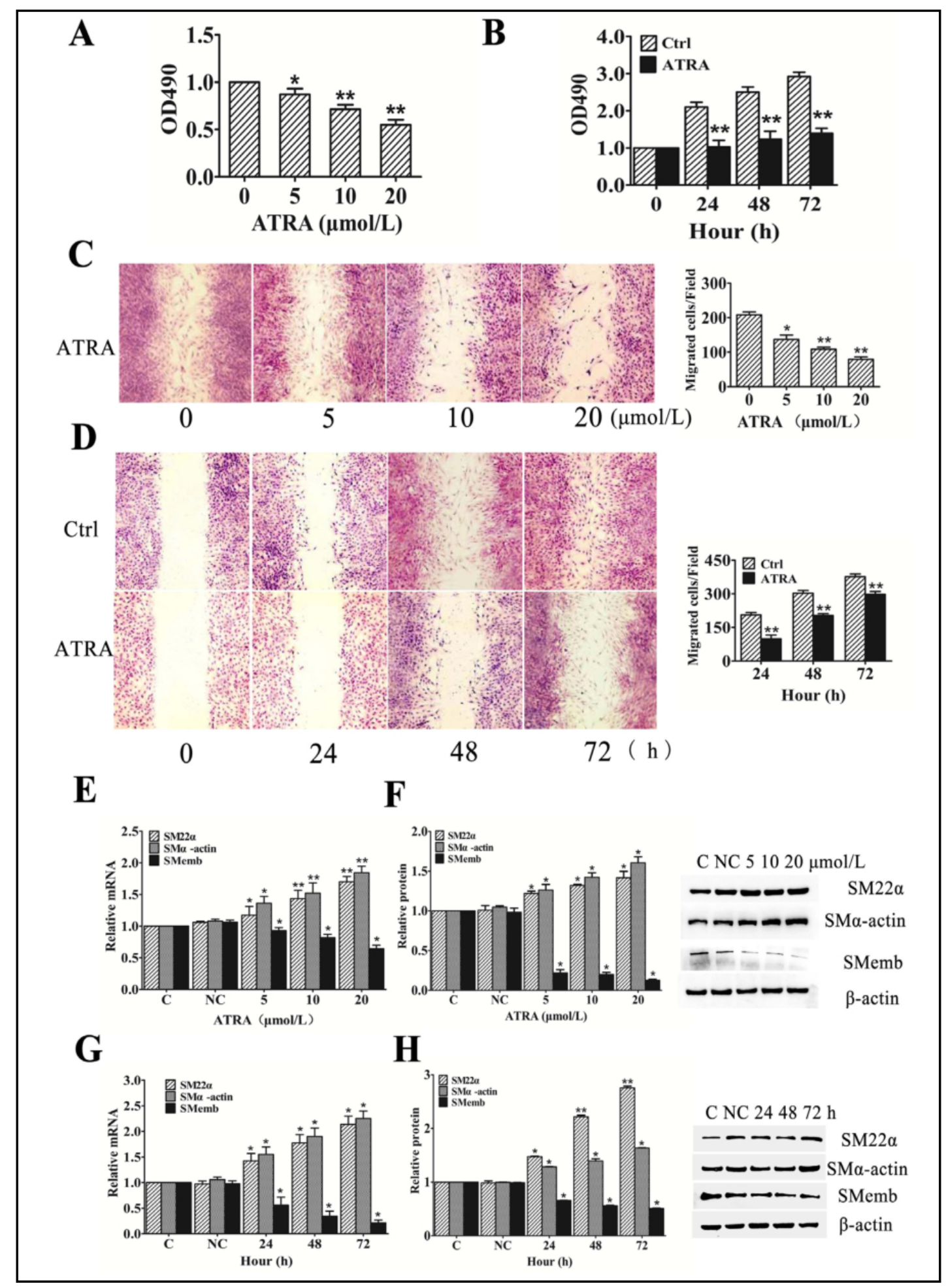

Fig. 1. ATRA inhibits cell proliferation and migration while promoting differentiation in VSMCs. VSMCs were incubated with different concentrations of ATRA $(0,5,10,20 \mu \mathrm{mol} / \mathrm{L})$ for $24 \mathrm{~h}$ or with ATRA $(20 \mu \mathrm{mol} / \mathrm{L})$ for different time intervals $(0,24,48,72 \mathrm{~h})$. MTT colorimetric assays (A and B) and cell migration assays (C and D) were used to detect changes in proliferation and migration. Magnification, $\times 100$. Expression of SM22 $\alpha$, SM $\alpha$-actin, and SMemb was detected by Q-PCR (E and G) and western blot (F and H). $\beta$-actin was used as the loading control. Data are means \pm SEM from three independent experiments, each performed in triplicate. ${ }^{* *} \mathrm{P}<0.01,{ }^{*} \mathrm{P}<0.05$ versus the control group.

\section{KARGER}




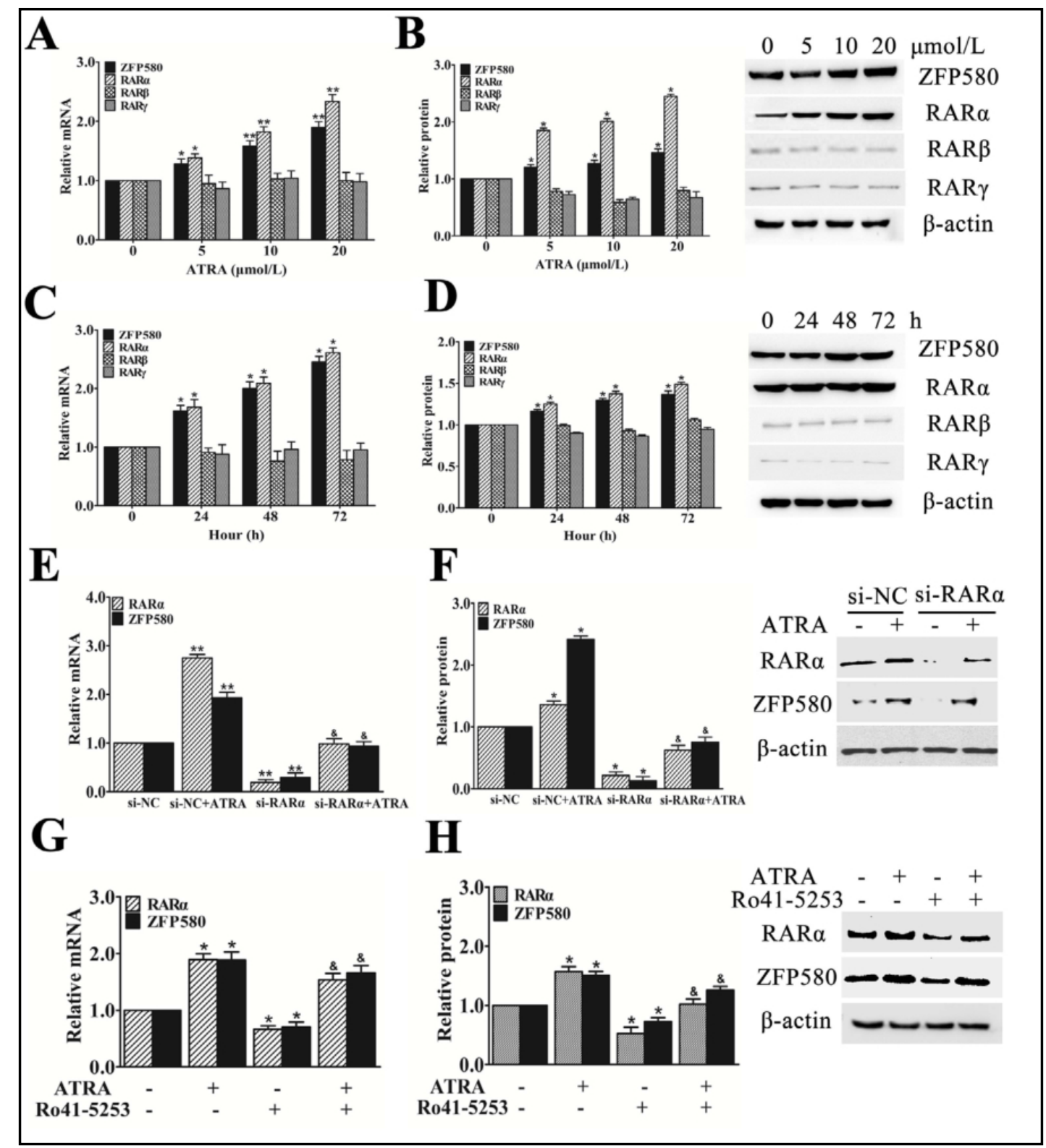

Fig. 2. ATRA-induced ZFP580 expression is RAR $\alpha$ dependent. VSMCs were treated with different concentrations of ATRA $(0,5,10,20 \mu \mathrm{mol} / \mathrm{L})$ for $24 \mathrm{~h}$ or with ATRA $(20 \mu \mathrm{mol} / \mathrm{L})$ for different time intervals $(0,24,48,72 \mathrm{~h})$. Q-PCR (A and C) and western blot (B and D) analysis of mRNA and protein levels, respectively, of ZFP580, RAR $\alpha, \operatorname{RAR} \beta$, and RAR $\gamma$. $\beta$-actin was an internal control. The bars represent the means \pm SEM from three independent experiments. ${ }^{*} \mathrm{P}<0.01$ and ${ }^{*} \mathrm{P}<0.05$ versus the ATRA-free group. VSMCs were transfected with si-RAR $\alpha$ or si-NS for $24 \mathrm{~h}$ and then treated with $20 \mu \mathrm{mol} / \mathrm{L}$ of ATRA for 24 h. Q-PCR (E) and western blot (F) analysis of mRNA and protein levels of ZFP580 and RAR $\alpha$. $\beta$-actin was an internal control. The bars represent the means \pm SEM from three independent experiments. ${ }^{* *} \mathrm{P}<0.01$, ${ }^{*} \mathrm{P}<0.05$ versus the si-NC group; $\& \mathrm{P}<0.05$ versus the si-RAR $\alpha$ group. VSMCs were pretreated with $20 \mu \mathrm{mol} / \mathrm{L}$ Ro $41-5253$ for $1 \mathrm{~h}$ prior to exposure to ATRA ( $20 \mu \mathrm{mol} / \mathrm{L})$ for $24 \mathrm{~h}$. Q-PCR (G) and western blot (H) analysis of mRNA and protein levels of ZFP580 and RAR $\alpha$. $\beta$-actin was an internal control. The bars represent the means \pm SEM from three independent experiments. ${ }^{* *} \mathrm{P}<0.01,{ }^{*} \mathrm{P}<0.05$ versus the control; $\& \mathrm{P}<0.05$ versus the ATRA group. 


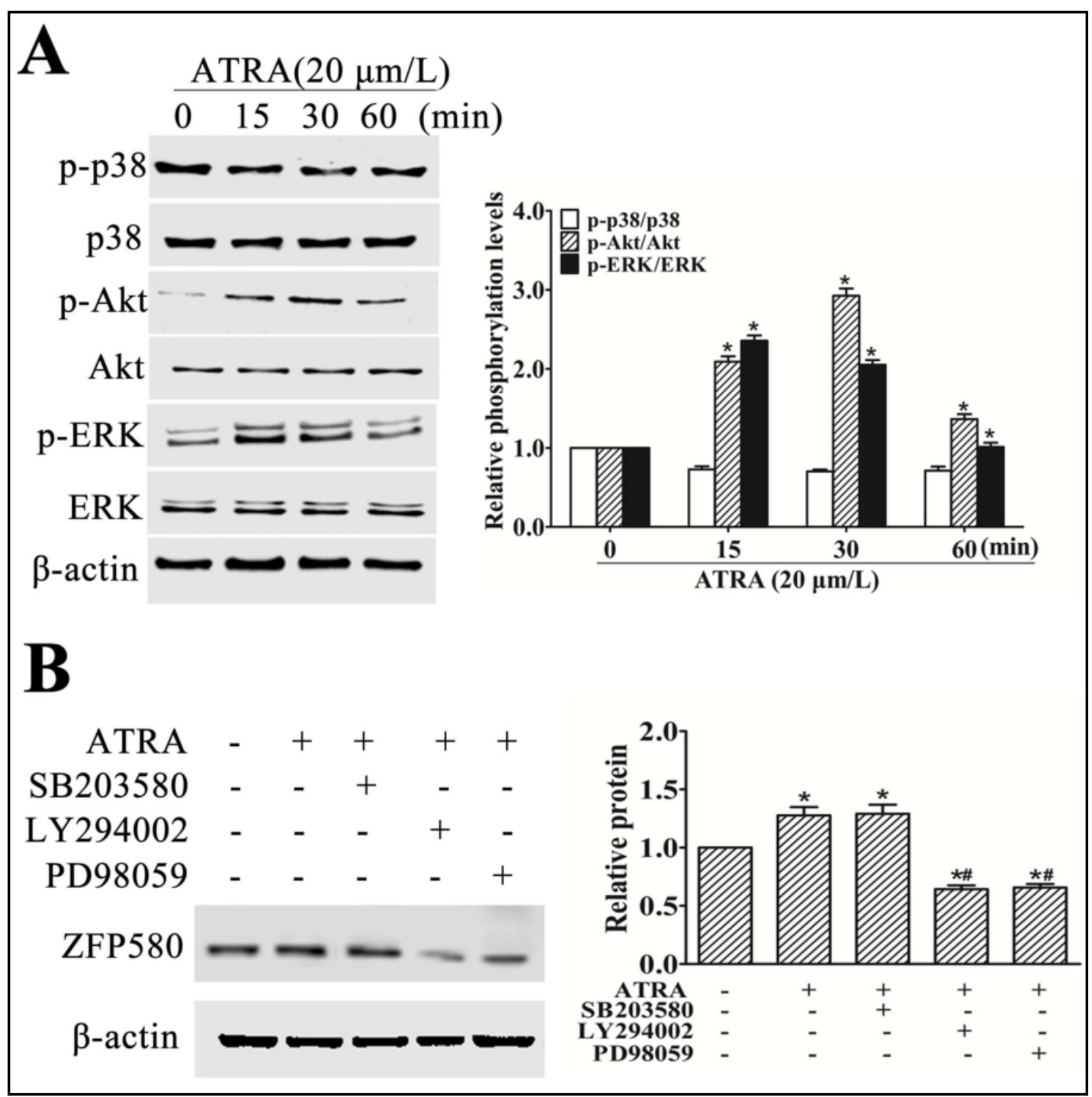

Fig. 3. ATRA induces ZFP580 expression via Akt and ERK signaling. (A) Cultured VSMCs were treated with $20 \mu \mathrm{mol} / \mathrm{L}$ ATRA for $60 \mathrm{~min}$. Phospho-p38, phospho-Akt, and phospho-ERK were analyzed by western blot with their respective antibodies. The total protein levels of p38, Akt, and ERK are also shown. Blots from a representative experiment are shown on the left, whereas band intensities of phosphorylated molecules normalized to their total counterpart are shown on the right. Data are shown as means \pm SEM from three independent experiments, each performed in triplicate. ${ }^{*} \mathrm{P}<0.05$ versus the control group ( $0 \mathrm{~min}$ ). (B) VSMCs were pretreated with SB203580, LY294002, or PD98059 for $2 \mathrm{~h}$, followed by 24-h incubation with ATRA $(20 \mu \mathrm{mol} / \mathrm{L})$. ZFP580 protein levels were analyzed by western blot with anti-ZFPP580 antibody. Blots from a representative experiment are shown on the left, whereas band intensities that were measured and normalized to $\beta$-actin are shown on the right. Data are means \pm SEM from three independent experiments, each performed in triplicate. ${ }^{*} \mathrm{P}<0.05$ versus the ATRA-free group; $\# \mathrm{P}<0.05$ versus the ATRA group. 


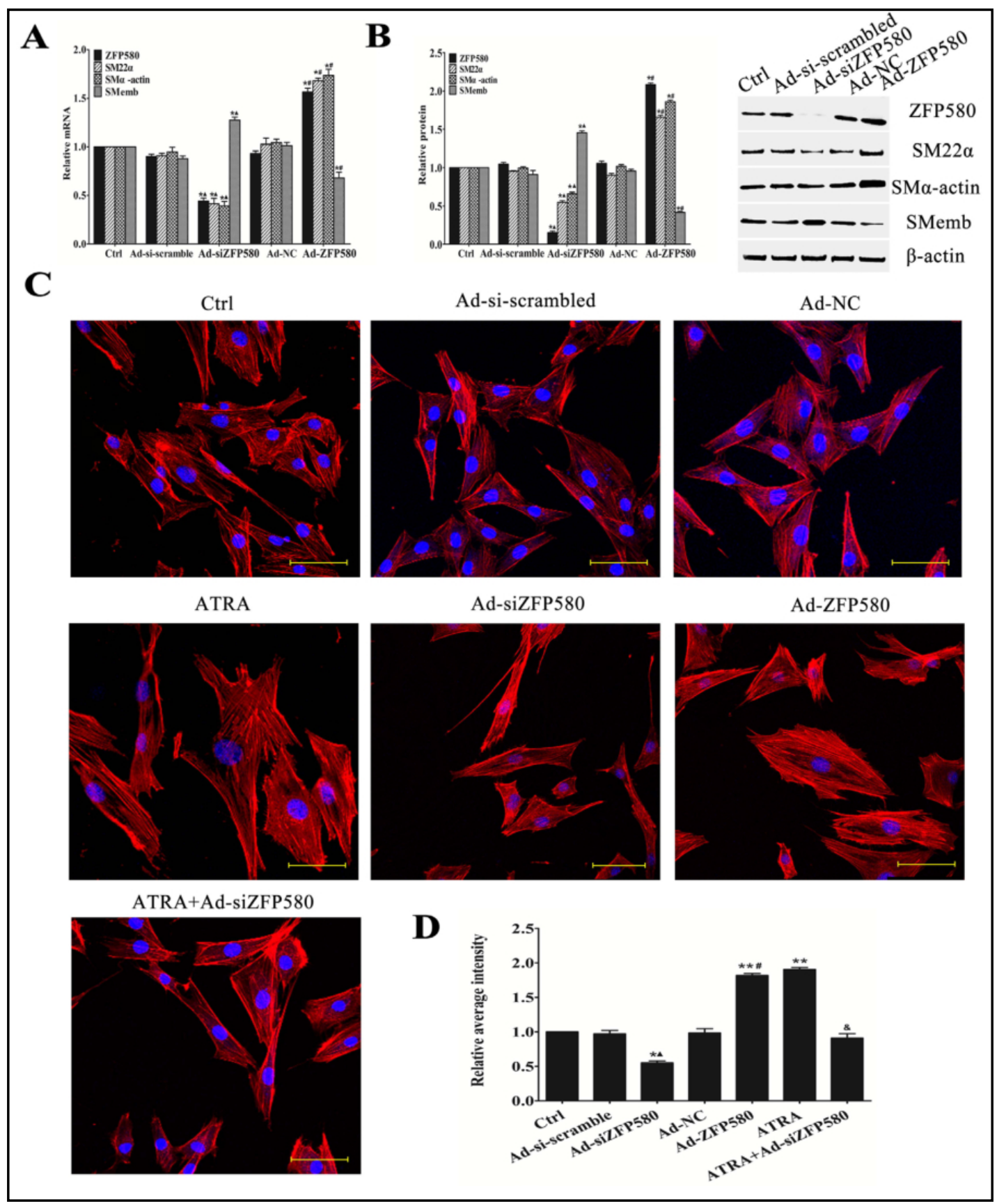

Fig. 4. The effects of ZFP580 on VSMC differentiation. VSMCs were infected with an adenovirus encoding ZFP580 (Ad-ZFP580) to overexpress ZFP580 or Ad-siRNA to silence ZFP580. In addition, infections with adenoviral control vector (Ad-NC) and recombinant adenovirus expressing a scrambled siRNA (Ad-siscrambled) were used as controls. Q-PCR analysis of mRNA levels of ZFP580, VSMC differentiation markers, and the dedifferentiation marker (A). Western blot analysis of protein levels of ZFP580, SM22 $\alpha$, SM $\alpha$-actin, and SMemb (B). $\beta$-actin was an internal control. VSMCs were infected with Ad-ZFP580 or Ad-siZFP580 and then fixed and immunostained for F-actin with tetramethyl rhodamine iso-thiocyanate (TRITC)-phalloidin (C). Quantitative intensity analysis for 30 cells per experiment (D). Scale bars are $75 \mu \mathrm{m}$. Data are means \pm SEM from three independent experiments, each performed in triplicate $\left({ }^{*} \mathrm{P}<0.05\right.$ versus control; $\# \mathrm{P}<0.05$ versus the Ad-NC group; $\Delta \mathrm{P}<0.05$ versus the Ad-si-scrambled group; $\& \mathrm{P}<0.05$ versus the ATRA group). 


\section{Cellular Physiology Cell Physiol Biochem 2018;50:2390-2405

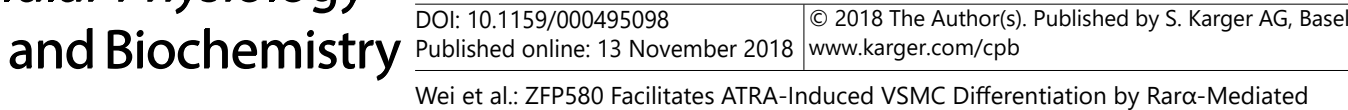 \\ PI3K/Akt and ERK Signaling}

The effects of ZFP580 on VSMC phenotypic switching

To explore the role of ZFP580 on VSMC phenotypic switching, VSMCs were infected with an adenovirus encoding ZFP580 or Ad-siRNA to silence ZFP580. The expression of ZNF580 was evaluated by Q-PCR and western blot (Fig. 4 A and B). Moreover, overexpression of ZFP580 caused a significant increase in mRNA and protein expression of SM22 $\alpha$ and SM $\alpha$ actin and decreased expression of the dedifferentiation marker SMemb compared with the negative control. In contrast, silencing ZFP580 dramatically reduced the expression of SM22 $\alpha$ and SM $\alpha$-actin and increased expression of SMemb (Fig. 4A and B).

Actin cytoskeleton reorganization plays a key role in regulating VSMC functionality, which, in turn, depends on the expression of its contractile proteins. We therefore sought to determine whether the overexpression or knockdown of ZFP580 affected the formation of stress fibers. ZFP580 overexpression markedly increased the formation of stress fibers. That is, the actin filaments were recruited into thick and long actin bundles by SM22a. Similarly, ATRA stimulation promoted the formation of stress fibers. When ZFP580 was knocked down, the formation of actin stress fibers induced by ATRA was reduced (Fig. 4C). Quantitative intensity analysis further indicates that ZFP580 promotes the formation of stress fibers in VSMCs (Fig. 4D).

\section{ZFP580 inhibited proliferation and intimal hyperplasia in vivo}

We examined the effect of ZFP580 on arterial walls in vivo using the classic rat carotid artery balloon injury model. The animals were killed on day 14 after treatment, for morphometric analysis of the cross-sections of the injured carotid arteries. Hematoxylin and eosin staining (Fig. 5A) revealed that the carotid arteries infected with the control adenovirus (Ad-NC) exhibited pronounced neointimal formation, while those infected with Ad-ZFP580 had significantly reduced neointimal hyperplasia. Intimal cell proliferation was evaluated with BrdU incorporation 7 days after balloon angioplasty, when the intimal proliferation peaked. The results showed that BrdU-incorporated intimal cells were decreased by approximately 50\% in the Ad-ZFP580 transduced arteries compared with the Ad-NC transduced arteries (Fig. 5B), indicating that ZFP580 inhibited intimal VSMCs proliferation in vivo. The expression of proliferating cell nuclear antigen (PCNA) in rat carotid arteries infected with Ad-ZFP580 or the control adenovirus (Ad-NC) was confirmed by immunohistochemical staining (Fig. 5C). PCNA and ZFP580 were also evaluated by western blot (Fig. 5D). These results demonstrated that ZFP580 suppressed the proliferation and neointimal hyperplasia of injured arteries. 
Wei et al.: ZFP580 Facilitates ATRA-Induced VSMC Differentiation by Rar $\alpha$-Mediated PI3K/Akt and ERK Signaling

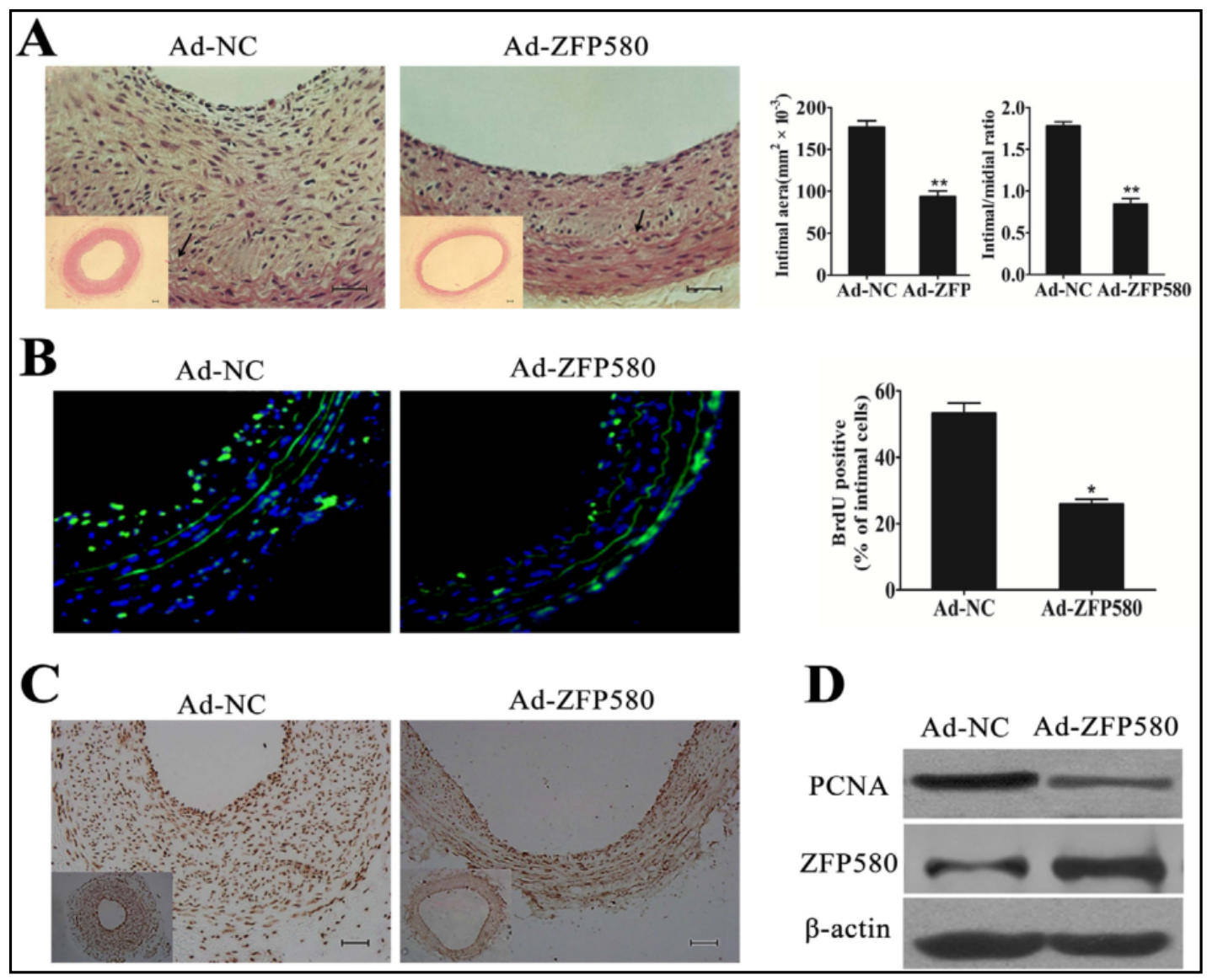

Fig. 5. Overexpression of ZFP580 inhibited neointimal formation. Rat carotid arteries were balloon-injured and infected with Ad-ZFP580 or with Ad-NC. Vessel segments were harvested 14 days later, and (A) crosssections were stained with hematoxylin and eosin staining to evaluate neointimal formation. Intimal and medial areas were measured and expressed as means \pm SEM of neointimal area $\left(\mathrm{mm}^{2}\right)$ and intima-to-media ratio (I/M) ( $\mathrm{n}=11$ for $\mathrm{NC}, \mathrm{n}=10$ for ZFP580). Arrows indicate the internal elastic lamina, whose corrugated appearance is indicative of vasoconstriction. Magnification, $\times 200$. Rat carotid arteries were balloon injured and infected with Ad-ZFP580 or with Ad-NC. Vessel segments were harvested 7 days later for analysis using (B) BrdU, (C) immunohistochemical staining of PCNA, and (D) western blot (in which the parental adenoviral vector was used as an infection negative control. The bar graph indicates the percentage of BrdUpositive cells in the neointima ( $\mathrm{n}=4$ for each group). Scale bar $=100 \mu \mathrm{m},{ }^{* *} \mathrm{P}<0.01,{ }^{*} \mathrm{P}<0.05$, significantly different from values with Ad-NC.

\section{Discussion}

KLFs form a large family of transcription factors that share in common a transcriptional activation/repression domain, a nuclear localization signal, and three Krüppel-like zinc fingers [29]. They have important biological functions in cell proliferation, apoptosis, development, and oncogenic processes [19-21]. The deduced ZNF580 amino acid sequence contains three tandem repeated $\mathrm{C} 2 \mathrm{H} 2$-type zinc fingers at the $\mathrm{C}$-terminus, a protein structure that is similar to that of KLFs. ZFP580 has been shown to play a key role in pathological vascular processes; however, its role in VSMC differentiation under pathophysiological conditions remains unclear. Here, we investigated the effect of ZFP580 on VSMC phenotypic switching, function, and its underlying mechanism.

Proper regulation of VSMC differentiation and growth is critical for vasculogenesis and the maintenance of homeostasis of mature vessel walls $[2,4,5]$. Perturbations of the molecular circuitry governing VSMC differentiation and growth are thought to be of central 
Wei et al.: ZFP580 Facilitates ATRA-Induced VSMC Differentiation by Rara-Mediated

PI3K/Akt and ERK Signaling

importance in the pathogenesis of atherosclerosis, hypertension, and restenosis after procedural revascularization. The identification of membrane-bound receptors and the delineation of their respective signaling pathways have yielded insight into the mechanisms that control VSMC differentiation and growth and have provided molecular targets for therapy of vascular disease [6-8]. In recent years, several nuclear receptor binding factors have been shown to regulate VSMC differentiation and growth. The steroid receptor superfamily has been of particular interest in this regard [30]. Steroid receptors are ligandactivated transcription factors that bind discrete cis elements within the regulatory regions of a growing list of target genes. This family of nuclear receptors includes estrogen receptors, the vitamin D receptor, peroxisome proliferator-activated receptors, and retinoid receptors [31-33]. Retinoids and the receptors they bind are recognized as having an increasingly important role in both cardiovascular development and the response of blood vessels to injury. Retinoids are natural and synthetic derivatives of vitamin A (retinol) [9]. The discovery of all-trans retinoic acid (ATRA) as the carboxylic acid form of vitamin A led to studies that ascribed virtually all of the biological effects of vitamin A to this natural retinoid [12]. Thus, ATRA plays a vital role in normal embryogenesis and in such postnatal processes as skin and epithelial homeostasis, hematopoiesis, and spermatogenesis [34]. An important early discovery was the demonstration that ATRA could promote cellular differentiation in vitro [35]. These findings led to the use of ATRA and other natural and synthetic retinoids for the treatment of cancer [36]. Today, ATRA is a standard therapy for the management of acute promyelocytic leukemia and is in various phases of clinical trials for a number of other hematological and solid tumors [10,37]. The common mechanisms underlying cancer and cardiovascular diseases (i.e., perturbations in differentiation and growth) suggest that retinoids could also be of therapeutic value in the treatment of certain vascular diseases. A number of in vitro and in vivo studies have shown that ATRA can positively influence VSMC differentiation programs $[14,15]$. Consistent with these findings, we shown that ATRA treatment significantly reduced VSMC proliferation and migration in a dose- and timedependent manner. Moreover, VSMCs incubated with ATRA exhibited enhanced expression of the differentiation makers and decreased expression of the dedifferentiation marker. Our results suggest that the ATRA inhibits cell proliferation and migration while promoting differentiation of VSMCs.

ATRA exerts its pleiotropic biological effects through receptor-mediated changes in gene expression, that is, RAR $\alpha$ and RXR. The mRNA expression of RAR $\alpha, R X R \alpha$, and RXR $\beta$ is ubiquitous, whereas RAR $\beta$ (central nervous system), RAR $\gamma$ (skeletal muscle precursors and skin and lung epithelia), and RXR $\gamma$ (skeletal muscle) exhibit tissue-restricted patterns of expression $[13,38]$. Studies utilizing cultured SMCs and adult aorta tissue have documented the mRNA expression of all retinoid receptors except for RXR $\gamma$ [39]. In the present study, we explore the role of RARs and the relationship between ZFP580 and RARs in response to ATRA signaling. In VSMCs, we discovered that treatment with ATRA induced the expression of ZFP580 and RAR $\alpha$. However, there was no significant change in RAR $\beta$ and RAR $\gamma$ induced by ATRA treatment. Silencing or inhibition of the RAR $\alpha$ gene with its antagonist Ro41-5253 abrogated ATRA-induced ZFP580 transcription, indicating that RAR $\alpha$ plays a critical role in the induction of ZFP580 by ATRA and cannot be substituted by other RARs. Reports revealed that ATRA can activate multi-signaling pathways, including the MAPK, PI3-kinase/Akt, cAMP-dependent protein kinase $A$, and protein kinase $C$ pathways. The present study shows that ATRA induced ZFP580 expression via the PI3K/Akt and ERK-mediated signal pathways. These findings indicated that ZFP580 might participate in ATRA-induced VSMC phenotype modulation.

Differentiation of VSMCs is characterized by the appearance of SMC-specific contractile proteins (e.g., SM $\alpha$-actin, SM22 $\alpha$, and SMemb), the expression of which is restricted to the SMC lineage and required for SMC contraction and regulation of blood pressure under adult physiologic conditions [40]. However, in response to vascular injury or within atherosclerotic lesions, VSMCs exhibit decreased expression of SMC marker proteins and increased migration, proliferation, and the production of extracellular matrix components 


\section{Cellular Physiology Cell Physiol Biochem 2018;50:2390-2405 \\ and Biochemistry \begin{tabular}{l|l} 
Dublished onlıne: 13 November 2018 & $\begin{array}{l}\text { (c) } 2018 \text { The Author(s). Published by S. Karger AG, Basel } \\
\text { www.karger.com/cpb }\end{array}$ \\
\hline Wei et al. ZFP580 Facilitates ATRA-Induced VSMC Differentiation by Rara-Mediated
\end{tabular} \\ PI3K/Akt and ERK Signaling}

as well as matrix metalloproteinases [4]. Transcriptional control of VSMC gene expression plays a central role in the control of VSMC phenotypic plasticity. Phenotypic switching is governed by the activity of a transcription factor network. KLFs are a critical component of such networks, which play critical roles in the physiology and pathophysiology of many organ systems, including cardiovascular, respiratory, digestive, hematological, and immune systems [19-21]. There have been reports that KLF4 promotes VSMC differentiation by increasing SMC marker protein levels [41]. Overexpression of KLF4 inhibits neointimal hyperplasia induced by balloon injury by inhibiting c-Jun expression [42]. Furthermore, it was also reported that ATRA activated SM22a expression through KLF4 binding to its ciselements in an acetylation-dependent manner and inhibited VSMC differentiation [14]. Our previous studies have shown that the novel zinc-finger transcription factor ZFP580 plays important roles in endothelial biology and cardiovascular disease [24-26]. We then evaluated the role of ZFP580 in VSMC biology using both gain- and loss-of-function analyses. The up-regulation of differentiation markers induced by overexpression of ZFP580 and the increased formation of stress fibers strongly suggest that ZFP580 induces VSMC differentiation. The dedifferentiation marker SMemb was also down-regulated after ZFP580 overexpression and up-regulated by ZFP580 knockdown, indicating that ZFP580 was an inducer of VSMC differentiation. To further define the role of ZFP580 in the control of VSMC phenotypic modulation, we constructed the classic rat carotid artery injury model. We found that ZFP580 overexpression inhibited neointimal hyperplasia.

\section{Conclusion}

In conclusion, the present study demonstrates that ZFP580 facilitates ATRA-induced VSMCs differentiation by the RAR $\alpha$-mediated PI3K/Akt and ERK signaling pathways. The present results thus describe a novel mechanism of regulation of ZFP580 by ATRA and RAR $\alpha$, which is vital to understand the biological functions of retinoids during VSMC phenotypic modulation.

\section{Abbreviations}

ATRA (All-trans retinoic acid); C2H2 (Cys2-His2); FBS (Fetal bovine serum); HRP (Horseradish peroxidase); KLF (Krüppel-like transcription factor); PCNA (Proliferating cell nuclear antigen); Q-PCR (Quantitative real-time polymerase chain reaction); RAR (Retinoic acid receptor); RXR (Retinoid X receptor); siRNA (Small-interfering RNA); SMemb (embryonic vascular smooth muscle myosin heavy chain-B); VSMCs (Vascular smooth muscle cells).

\section{Acknowledgements}

This work was supported by grants from the Chinese National Natural Science Foundation (No. 81170106, No. 81370439); Tianjin Natural Science Foundation (No. 15JCQNJC09400) and the Science Foundation of PAPF Logistics University (No. FYZ201509, No. WHJ201406, No. WHTD201301-3, No. WHB201203). We are grateful to our colleagues in the Department of Physiology and Pathophysiology, Logistics University of Chinese People's Armed Police Force (PAPF), for their excellent technical assistance and encouragement.

\section{Disclosure Statement}

The authors confirm that there are no conflicts of interest.

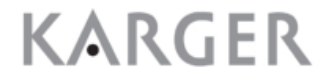




\section{Cellular Physiology Cell Physiol Biochem 2018;50:2390-2405 \begin{tabular}{l|l|l} 
and Biochemistry Published online: 13 November 2018 & $\begin{array}{l}\text { (c) } 2018 \text { The Author(s). Published by S. Karger AG, Basel } \\
\text { www.karger.com/cpb }\end{array}$
\end{tabular}}

Wei et al.: ZFP580 Facilitates ATRA-Induced VSMC Differentiation by Rar $\alpha$-Mediated

PI3K/Akt and ERK Signaling

\section{References}

1 Bennett MR, Sinha S, Owens GK: Vascular smooth muscle cells in atherosclerosis. Circulation Res 2016;118:692-702.

-2 Zheng B, Han M, Wen JK: Role of Krüppel-like factor 4 in phenotypic switching and proliferation of vascular smooth muscle cells. IUBMB Life 2010;62:132-139.

- 3 Cines DB, Pollak ES, Buck CA, Loscalzo J, Zimmerman GA, McEver RP, Pober JS, Wick TM, Konkle BA, Schwartz BS, Barnathan ES, McCrae KR, Hug BA, Schmidt AM, Stern DM: Endothelial cells in physiology and in the pathophysiology of vascular disorders. Blood 1998;91:3527-3561.

4 Chang S, Song S, Lee J, Yoon J, Park J, Choi S, Park JK, Choi K, Choi C: Phenotypic modulation of primary vascular smooth muscle cells by short-term culture on micropatterned substrate. PLoS One 2014;9:e88089.

-5 Schadler KL, Zweidler-McKay PA, Guan H, Kleinerman ES: Delta-like ligand 4 plays a critical role in pericyte/vascular smooth muscle cell formation during vasculogenesis and tumor vessel expansion in Ewing's sarcoma. Clin Cancer Res 2010;16:848-856.

-6 Schreier B, Schwerdt G, Heise C, Bethmann D, Rabe S, Mildenberger S, Gekle M: Substance-specific importance of EGFR for vascular smooth muscle cells motility in primary culture. Biochim Biophys Acta 2016;1863:1519-1533.

7 Sugo S, Minamino N, Shoji H, Kangawa K, Matsuo H: Effects of vasoactive substances and cAMP related compounds on adrenomedullin production in cultured vascular smooth muscle cells. FEBS Lett 1995;369:311-314.

-8 Kavurma MM, Tan NY, Bennett MR: Death receptors and their ligands in atherosclerosis. Arterioscler Thromb Vasc Biol 2008;28:1694-1702.

-9 Cristiano MC, Cosco D, Celia C, Tudose A, Mare R, Paolino D, Fresta M: Anticancer activity of all-trans retinoic acid-loaded liposomes on human thyroid carcinoma cells. Colloids Surf B Biointerfaces 2017;150:408-416.

-10 Schlenk RF, Lübbert M, Benner A, Lamparter A, Krauter J, Herr W, Martin H, Salih HR, Kündgen A, Horst HA, Brossart P, Götze K, Nachbaur D, Wattad M, Köhne CH, Fiedler W, Bentz M, Wulf G, Held G, Hertenstein B et al.: All-trans retinoic acid as adjunct to intensive treatment in younger adult patients with acute myeloid leukemia: results of the randomized AMLSG 07-04 study. Ann Hematol 2016;95:1931-1942.

11 Czarnewski P, Das S, Parigi SM, Villablanca EJ: Retinoic acid and its role in modulating intestinal innate immunity. Nutrients 2017;9:E68.

12 Xu Y, Gao AM, Ji LJ, Li X, Zhong LL, Li HL, Zheng DH: All-trans retinoic acid attenuates hypoxia-induced injury in NRK52E cells via inhibiting NF-x03BA; B/VEGF and TGF- $\beta 2 /$ VEGF pathway. Cell Physiol Biochem 2016;38:229-236.

13 Di Masi A, Leboffe L, De Marinis E, Pagano F, Cicconi L, Rochette-Egly C, Lo-Coco F, Ascenzi P, Nervi C: Retinoic acid receptors: from molecular mechanisms to cancer therapy. Mol Aspects Med 2015;41:1-115.

14 Yu K, Zheng B, Han M, Wen JK: ATRA activates and PDGF-BB represses the SM22 $\alpha$ promoter through KLF4 binding to, or dissociating from, its cis-DNA elements. Cardiovasc Res 2011;90:464-474.

15 Lee CW, Park SJ, Park SW, Kim JJ, Hong MK, Song JK: All-trans-retinoic acid attenuates neointima formation with acceleration of reendothelialization in balloon-injured rat aorta. J Korean Med Sci 2000;15:31-36.

-16 Zakkar M, Angelini GD, Emanueli C: Regulation of Vascular Endothelium Inflammatory Signalling by Shear Stress. Curr Vasc Pharmacol 2016;14:181-186.

17 Lee SJ, Park SS, Kim WJ, Moon SK: Gleditsia sinensis thorn extract inhibits proliferation and TNF- $\alpha$-induced MMP-9 expression in vascular smooth muscle cells. Am J Chin Med 2012;40:373-386.

18 Zheng JP, Ju D, Jiang H, Shen J, Yang M, Li L: Resveratrol induces p53 and suppresses myocardin-mediated vascular smooth muscle cell differentiation. Toxicol Lett 2010;199:115-122.

19 Suzuki T, Aizawa K, Matsumura T, Nagai R: Vascular implications of the Krüppel-like family of transcription factors. Arterioscler Thromb Vasc Biol 2005;25:1135-1141.

20 Kobus K, Kopycinska J, Kozlowska-Wiechowska A, Urasinska E, Kempinska-Podhorodecka A, Haas TL, Milkiewicz P, Milkiewicz M: Angiogenesis within the duodenum of patients with cirrhosis is modulated by mechanosensitive Kruppel-like factor 2 and microRNA-126. Liver Int 2012;32:1222-1232. 


\section{Cellular Physiology Cell Physiol Biochem 2018;50:2390-2405 \begin{tabular}{l|l|l|l|l}
\hline DOI: 10.1159/000495098 2018 The Author(s). Published by S. Karger AG, Basel & and Biochemistry \\
\hline
\end{tabular} and Biochemistry}

Wei et al.: ZFP580 Facilitates ATRA-Induced VSMC Differentiation by Rara-Mediated

PI3K/Akt and ERK Signaling

21 Courboulin A, Tremblay VL, Barrier M, Meloche J, Jacob MH, Chapolard M, Bisserier M, Paulin R, Lambert C, Provencher S, Bonnet S: Krüppel-like factor 5 contributes to pulmonary artery smooth muscle proliferation and resistance to apoptosis in human pulmonary arterial hypertension. Respir Res 2011;12:128.

22 Zeng WW, Chen BS, Zhang WC: Cloning and tissue expression of a novel gene down-regulated by low density lipoprotein. Basic Med. Sci. Clin 2003;23:279-282.

23 Zhu YB, Zhang WC: Cloning and analyzing of the cDNA sequence of N-terminal region and C-terminal region of zinc finger protein (ZFP580) gene. Life Sci 2008;5:11-16.

-24 Meng XY, Yu HL, Zhang WC, Wang TH, Mai X, Liu HT, Xu RC: ZFP580, a novel zinc-finger transcription factor, is involved in cardioprotection of intermittent high-altitude hypoxia against myocardial ischemiareperfusion injury. PLoS One 2014;9:e94635.

25 Wei S, Huang J, Li Y, Zhao J, Luo Y, Meng X, Sun H, Zhou X, Zhang M, Zhang W: Novel zinc finger transcription factor ZFP580 promotes differentiation of bone marrow-derived endothelial progenitor cells into endothelial cells via eNOS/NO pathway. J Mol Cell Cardiol 2015;87:17-26.

26 Sun HY, Wei SP, Xu RC, Xu PX, Zhang WC: Sphingosine-1-phosphate induces human endothelial VEGF and MMP-2 production via transcription factor ZNF580: novel insights into angiogenesis. Biochem Biophys Res Commun 2010;395:361-366.

-27 Jung SM, Park SS, Kim WJ, Moon SK: Ras/ERK1 pathway regulation of p27KIP1-mediated G1-phase cellcycle arrest in cordycepin-induced inhibition of the proliferation of vascular smooth muscle cells. Eur J Pharmacol 2012;681:15-22.

28 Ramachandran P, Reddy RP, Rao MS, Jayaram AA: A novel approach for the retrieval of broken catheter fragment-using balloon dilatation technique. J Clin Diagn Res 2016;10:0D10-1.

-29 Feinberg MW, Wara AK, Cao Z, Lebedeva MA, Rosenbauer F, Iwasaki H, Hirai H, Katz JP, Haspel RL, Gray S, Akashi K, Segre J, Kaestner KH, Tenen DG, Jain MK: The Kruppel-like factor KLF4 is a critical regulator of monocyte differentiation. EMBO J 2007;26:4138-4148.

-30 Evans RM: The steroid and thyroid hormone receptor superfamily. Science 1988;240:889-895.

-31 Mendelsohn ME, Karas RH: The protective effects of estrogen on the cardiovascular system. N Engl J Med 1999;340:1801-1811.

32 Mitsuhashi T, Morris RC Jr, Ives HE: 1, 25-Dihydroxyvitamin D3 modulates growth of vascular smooth muscle cells. J Clin Invest 1991;87:1889-1895.

-33 Fruchart JC, Duriez P, Staels B: Peroxisome proliferator-activated receptor-alpha activators regulate genes governing lipoprotein metabolism, vascular inflammation and atherosclerosis. Curr Opin Lipidol. 1999;10:245-257.

-34 Ross SA, McCaffery PJ, Drager UC, DeLuca LM: Retinoids in embryonal development. Physiol Rev 2000;80:1021-1054.

-35 Breitman TR, Selonick SE, Collins SJ: Induction of differentiation of the human promyelocytic leukemia cell line (HL-60) by retinoic acid. Proc Natl Acad Sci U S A 1980;77:2936-2940.

-36 Lippman SM, Heyman RA, Kurie JM, Benner SE, Hong WK: Retinoids and chemoprevention: clinical and basic studies. J Cell Biochem Suppl 1995;22:1-10.

-37 Tallman MS, Anderson JW, Schiffer CA, Appelbaum FR, Feusner JH, Ogden A, Shepherd L, Willman C, Bloomfield CD, Rowe JM, Wiernik PH: All-trans retinoic acid in acute promyelocytic leukemia. N Engl J Med 1997;337:1021-1028.

38 Cañete A, Cano E, Muñoz-Chápuli R, Carmona R: Role of vitamin A/retinoic acid in regulation of embryonic and adult hematopoiesis. Nutrients 2017;9:E159.

-39 Streb JW, Long X, Lee TH, Sun Q, Kitchen CM, Georger MA, Slivano OJ, Blaner WS, Carr DW, Gelman IH, Miano JM: Retinoid-induced expression and activity of an immediate early tumor suppressor gene in vascular smooth muscle cells. PLoS One 2011;6:e18538.

40 Mao X, Debenedittis P, Sun Y, Chen J, Yuan K, Jiao K, Chen Y: Vascular smooth muscle cell Smad4 gene is important for mouse vascular development. Arterioscler Thromb Vasc Biol 2012;32:2171-2177.

41 Wang C, Han M, Zhao XM, Wen JK: Kruppel-like factor 4 is required for the expression of vascular smooth muscle cell differentiation marker genes induced by all-trans retinoic acid. J Biochem 2008;144:313-321.

42 Yoshida T, KaestnerKH, Owens GK: Conditional deletion of Krüppel-like factor 4 delays downregulation of smooth muscle cell differentiation markers but accelerates neointimal formation following vascular injury. Circ Res 2008;102:1548-1557. 